\title{
Measuring Solvency In The Turkish Public Transportation Industry
}

\section{Cem Berk, Kamil Erguler}

\author{
Istanbul Arel University, Turkey \\ Associate Professor of Finance \\ Turkoba Mah. Erguvan Sok. No.26/K Tepekent-Buyukcekmece-Istanbul-Turkey \\ IETT (Istanbul Public Transportation Company), Turkey \\ Collection Manager IETT Headquarters \\ Sahkulu Mahallesi, Erkani Harp Sk. No:2, 34420 Beyoglu/İstanbul
}

\begin{abstract}
Financial analysis is a combined effort of knowledge and experience to obtain relevant ratios and elaborate on the results. The study is an application of financial analysis on Istanbul Public Transportation Company. As seen in the literature review section of the study public transportation companies require high subsidies by governments which is a factor to consider in the research. The research period is 20142016. It is a comparative study with the inclusion of Izmir - ESHOT and Ankara - EGO public transportation companies. The results are therefore compared with industry averages computed by the average of public transportation companies of three big cities in Turkey. The research is based on 7 selected ratios, 3 for measuring liquidity and the remaining 4 for measuring solvency. The ratios used in this paper are current ratio, acid test ratio, cash ratio, total debt ratio, debt equity ratio, equity multiplier, and long term debt ratio. According to the results, the companies have a very low current ratio which means they operate with low liquidity. Solvency analysis also reveal that, there are high degrees of leverage and negative shareholders' equity. The research shows that companies might struggle to repay debts without government support.
\end{abstract}

Key Words: Financial Analysis, Public Transportation, Liquidity, Solvency.

JEL Classification: G32, G33, H25, L32.

\section{Introduction}

Financial analysis is a study in corporate finance with an idea of using some techniques to compute some ratios that give information about the current state of the company. These ratios can be obtained by dividing some data from the company's financial statements to others. This can later be used to evaluate the performance of the companies in the previous periods, to determine financial structure, and to compare the results with competitors within the same industry or with industry averages. Today many state owned companies also focus on these studies to fulfill the requirements in performance based budgets.

Financial statements basically include every relevant information that has monetary value. Therefore, a risk management should be applied with these companies. These efforts may be the use of derivative instruments, insurance or portfolio based investments or today one can determine potential risks and even audit problems with financial analysis. Financial ratios are therefore frequently used by financial analysts, investors, managers and state institutions.

Financial analysis is a science yet it requires critical thinking skills to elaborate on the results. Depending on the experience and goal of the analyst, the results can tell a lot on the company.

Financial analysis is not only about analyzing past performance, and present situation but also a systematic approach to evaluate financial decisions and strategies. 
In this research financial analysis, more specifically liquidity and solvency ratios are studied for public transportation institutions operating in Turkey. Three institutions from Istanbul, Ankara and Izmir- 3 big cities in Turkey are selected for this purpose.

Public transportation companies are state owned companies that effect vast majority of the society. Stable operation of these companies and their financial concerns are also discussed in the literature. This research has the goal of evaluating short term and long term financial solvency of these companies.

The remainder of the paper is organized as follows. In chapter 2 the works on public transportation in the literature are analyzed. In Chapter 3, the methodology of the research is given and the ratios which are used in the research are explained. In Chapter 4, the ratios are calculated for all of the companies for the period 2014-2016 and industry averages are also provided. In chapter 5 the results of the research are discussed in more detail. Finally, chapter 6 includes final comments and implications.

\section{Literature Review}

It is not easy to make a feasibility study on transport infrastructure. This is because the financial returns from the social impacts are not easily computable in most situations.

Bekefi et al. (2003) have a paper on using software to decide on large scale transport infrastructure investments. The idea is to combine a complex financial feasibility with monetarized social impacts of the project. This process also includes quantifying the priority of several objectives and performing sensitivity analysis.

The public transportation companies have many functions that are directly linked with economy. Their performance often benefits the lower income group in the society.

Anna Matas and Raymond (2003) worked on redistributive effects of urban public transport services. They considered car ownership decisions and expenditure on public transport. They find out that subsidies benefit especially lower income group and they are more effective in larger cities.

Although not a direct duty of IETT, the ship transportation is also effective. However, the industry is capital intensive and complex financial transactions might be required. For the period 2014-2016, the role of IETT with ship transportation is only to make payments due to the use of electronic tickets. Later in 2017, IETT transferred this duty to the Istanbul Metropolitan Municipality.

Akca E.C. (2007) pointed out the trends in the shipping finance. The capital intensive industry is financed in many countries not only in their own country. This includes both equity and debt financing. Banks tend to finance more when the economy is growing.

The transportation often requires subsidies by governments. However over subsidization might have negative effects for the budgets.

Vassallo et al. (2009) focused on public transport funding policy. The transportation system in Madrid involves high subsidies might risk the financial viability of the city transport system in the future.

Many economists argue that the governments should only be active in areas where there is no profitable investment opportunity for private companies. When there are such opportunities, they tend to work with private companies in a process called Public Private Partnerships. (PPP)

Wang and Zhao (2014) studied the role of public private partnership in toll road financing in United Stated during 1985-2010. The results show that the probability of adopting PPP is affected by traffic demands, fiscal pressure, political issues, state wealth, legislation and earlier PPP in the state.

In financial analysis of transportation companies sector based indicators - often called key performance indicators might be used. This will also benefit the analysis because of the use of the sector based ratios.

Pintea et al. (2015) studied the performance of an urban transportation system. They argued that it is necessary to use key result indicators such as return on assets and return on equity, performance indicators 
such as economic value added and greenhouse gas emissions, and key performance indicators such as number of accidents and fraudulent travelers.

The efficiency of the transportation network should be monitored closely. Because of this, most governments need to apply performance based budgets in transportation as they do in other services.

Nieplowicz (2016) argue the use of performance budgets in metropolises of Poland to increase transport efficiency. They think that performance base budget should be widely used to increase efficiency by determining several goals.

The public transportation has many benefits. One of the most important is that it serves to reduce traffic accidents.

Poliak et al. (2017) researched on the effects of financing from public funds in passenger transport services. They focus on traffic density and fuel prices. They conclude that public financial support is a key factor in increasing road safety. Because using personal cars instead of public transport increases the level of risk.

\section{DATA AND METHODOLOGY}

The methodology of this thesis is to apply financial analysis techniques to the public transportation institutions in Turkey. These institutions are IETT from Istanbul, EGO from Ankara and ESHOT from Izmir. These are the three biggest cities in Turkey. They are responsible from the operation of public transportation in their cities.

The data is obtained from the audited financial statements of the institutions for the period 2014-2016. In the financial analysis part, some financial ratios for all of the three institutions are computed and evaluated. Therefore, it is possible to make individual analysis for these institutions as well as industrial analysis for their positions on the ratio analysis.

7 selected ratios are selected for the analysis. 3 of these ratios are in the liquidity ratios category and the remaining 4 ratios are in the solvency ratios category. Liquidity ratios indicate short term ability to repay the debts whereas solvency ratios are long term indicators. The ratios used in the research are current ratio, acid test ratio, and cash ratio for the liquidity ratios category and total debt ratio, debt-equity ratio, equity multiplier and long term debt ratio for the solvency ratios category.

\section{1. Liquidity Ratios}

Liquidity is a concept used for showing the ability of an institution to repay its short term debt. According to Aydin et al. (2007) liquidity concept can be defined as the ability of assets to transform into cash. Therefore, there are two important issues, the time that is required for the transformation and the protection of the value.

\subsection{Current Ratio}

According to Akguc(1995) the goal in calculating current ratio is to measure the ability to repay short term debt and to determine whether net working capital is adequate. Current ratio determines the capacity to repay debt better than net working capital.

\subsection{Acid Test Ratio}

Arat and Durmus (2000) argues that acid test ratio is complementary to current ratio. When calculating this ratio, assets with lower liquidity, inventory, other assets, and prepaid expenses are deducted from current assets. In other words, cash and assets that can easily be transformed into cash are divided to current liabilities to determine acid test ratio.

\subsection{Cash Ratio}

Cash ratio is a more sensitive liquidity ratio than the other ratios. Cabuk and Lazol (2009) point out that this ratio shows how well the company could cover its debts when there are no sales and receivables are not collected.

\subsection{Solvency Ratios}

Gokhan and Sezis(1996) correctly argue that solvency ratios gives important information whether the company will be able to repay the debts, when there is a loss, depreciation in value of the assets and the required cash flow doesn't occur. 


\subsubsection{Total Debt Ratio}

Okka (2010) says that the total debt ratio shows that how much the assets are financed with debt. General computation for total debt ratio is to divide total debt by total assets.

\subsubsection{Debt- Equity Ratio}

Okka (2010) views debt-equity ratio as another version of the total debt ratio. This shows how much the creditors and shareholders invest in the company. This is the level of financial leverage for the company. (Okka, 2010; 118/119)

\subsubsection{Equity Multiplier}

Equity multiplier shows how many times the assets are when compared with shareholders' equity. Lower ratio is less risky for the company. Equity multiplier is calculated by dividing total assets by shareholders' equity.

\subsubsection{Long Term Debt Ratio}

Solvency ratios are long term indicators of the company's ability to repay debts. It is calculated by dividing long term debts to the summation of long term debts and shareholders' equity. Since most investments are financed with long term debts and equity it is important to know how much of it is financed with debt.

\section{Results}

\subsection{Liquidity Ratios}

\subsubsection{Current Ratio}

Table 1 suggests that IETT has an average current ratio of 0,26 . For a creditor, this is a low ratio to repay liabilities.

Table 1. Current Ratio

\begin{tabular}{|llll|}
\hline Current Ratio & Current Assets & $/$ Current Liabilities & Results \\
\hline 2014 & $335.909 .912,87$ & $/ 1.134 .677 .638,50$ & $=0,30$ \\
\hline 2015 & $287.352 .797,25$ & $/ 858.400 .657,81$ & $=0,33$ \\
\hline 2016 & $122.201 .846,25$ & $/ 752.060 .401,34$ & $=0,16$ \\
\hline & Average & 0,26 \\
\hline
\end{tabular}

The industry average is presented in Table 2. Accordingly, industry average is 0,46. ESHOT has a higher average of 1,01, while the average of EGO is lower - 0,10.

Table 2- Industry Average - Current Ratio

\begin{tabular}{|c|c|c|c|c|}
\hline \multirow[b]{2}{*}{ YEAR } & \multicolumn{4}{|c|}{ INDUSTRY AVERAGE } \\
\hline & IETT & ESHOT & EGO & AVERAGE \\
\hline 2014 & 0,30 & 0,62 & 0,111 & 0,34 \\
\hline 2015 & 0,33 & 1,56 & 0,096 & 0,66 \\
\hline 2016 & 0,16 & 0,85 & 0,099 & 0,37 \\
\hline Average & 0,26 & 1,01 & 0,10 & 0,46 \\
\hline
\end{tabular}

\subsubsection{Acid Test Ratio}

The Acid Test Ratio of IETT is given in Table 3. Accordingly, IETT has an average acid test ratio of 0,23. Since the inventory is used limitedly in the industry, the current ratio is close to acid test ratio. 
Table 3- Acid Test Ratio

\begin{tabular}{|cccccc|}
\hline $\begin{array}{c}\text { Acid Test } \\
\text { Ratio }\end{array}$ & $\begin{array}{c}\text { Current Assets- } \\
\text { Inventory }\end{array}$ & $/$ & Curerent Liabilities & Results \\
\hline 2014 & $295.465 .047,07$ & $/$ & $1.134 .677 .638,50$ & $=0,26$ \\
\hline 2015 & $247.693 .476,49$ & $/$ & $858.400 .657,81$ & $=0,29$ \\
\hline 2016 & $96.814 .075,00$ & $/$ & $752.060 .401,34$ & $=0,13$ \\
\hline & & & Average & 0,23 \\
\hline
\end{tabular}

The industry average of acid test ratio is given in Table 4. As in the Current Ratio, the acid test ratio average of EGO is lower and that of ESHOT is higher.

Table 4 - Industry Average - Acid Test Ratio

\begin{tabular}{|c|c|c|c|c|}
\cline { 2 - 5 } \multicolumn{1}{c|}{} & \multicolumn{4}{c|}{ INDUSTRY AVERAGE } \\
\hline YEAR & IETT & ESHOT & EGO & AVERAGE \\
\hline 2014 & 0,26 & 0,52 & 0,078 & 0,29 \\
\hline 2015 & 0,29 & 1,36 & 0,068 & 0,57 \\
\hline 2016 & 0,13 & 0,74 & 0,069 & 0,31 \\
\hline Average & 0,23 & 0,87 & 0,07 & 0,39 \\
\hline
\end{tabular}

\subsubsection{Cash Ratio}

In Table 5, the cash ratio of IETT is given. Accordingly, IETT has an average of 0,12 for the period 20142016. Although cash ratio is a short term solvency indicator, holding too much cash is known to be inefficient.

Table 5-Cash Ratio

\begin{tabular}{|lrlll|}
\hline Cash Ratio & Cash & $/$ & Current Liabillities & Results \\
\hline 2014 & $176.439 .416,14$ & $/$ & $1.134 .677 .638,50$ & $=0,16$ \\
\hline 2015 & $153.061 .793,53$ & $/$ & $858.400 .657,81$ & $=0,18$ \\
\hline 2016 & $13.128 .701,30$ & $/$ & $752.060 .401,34$ & $=0,02$ \\
\hline & & Average & 0,12 \\
\cline { 3 - 4 } & & & An
\end{tabular}

The industry average of cash ratio is given in Table 6. Accordingly, IETT has higher cash ratio average than both ESHOT and EGO. 
Table 6- Industry Average - Cash Ratio

\begin{tabular}{|l|l|l|l|l|}
\hline \multicolumn{4}{|l}{ Industry Average } \\
\hline YIL & IETT & ESHOT & EGO & Mean \\
\hline 2014 & 0,16 & 0,08 & 0,004 & 0,08 \\
\hline 2015 & 0,18 & 0,14 & 0,001 & 0,11 \\
\hline 2016 & 0,02 & 0,05 & 0,008 & 0,02 \\
\hline Ort. & 0,12 & 0,09 & 0,00 & 0,07 \\
\hline
\end{tabular}

\subsection{Solvency Ratios}

\subsubsection{Total Debt Ratio}

The total debt ratio of IETT is computed in Table 7. Accordingly, IETT has an average of 0,64 for the period 2014-2016.

Table 7-Total Debt Ratio

\begin{tabular}{|c|c|c|c|}
\hline Total Debt Ratio= & $\begin{array}{l}\text { Total Assets - Total } \\
\text { Equity }\end{array}$ & / Total Assets & Results \\
\hline 2014 & $1.745 .373 .699,37$ & / 2.033.752.977,03 & $=0,86$ \\
\hline 2015 & $1.529 .013 .715,23$ & / $\quad 1.869 .768 .202,33$ & $=0,82$ \\
\hline \multirow[t]{2}{*}{2016} & $1.513 .918 .373,42$ & / $\quad 6.315 .098 .230,74$ & $=0,24$ \\
\hline & & Average & $=0,64$ \\
\hline
\end{tabular}

The industry average for the total debt ratio is tabulated in Table 8. Accordingly, IETT has a lower average than both ESHOT and EGO.

Table 8- Industry Average - Total Debt Ratio

\begin{tabular}{|l|l|l|l|l|}
\hline \multicolumn{6}{|l|}{ INDUSTRY A VERAGE } \\
\hline YEAR & IETT & ESHOT & EGO & AVERAGE \\
\hline 2014 & 0,86 & 1,03 & 1,591 & 1,16 \\
\hline 2015 & 0,82 & 0,76 & 1,652 & 1,08 \\
\hline 2016 & 0,24 & 0,61 & 1,812 & 0,89 \\
\hline Average & 0,64 & 0,80 & 1,68 & 1,04 \\
\hline
\end{tabular}

\subsubsection{Debt-Equity Ratio}


The total debt ratio for IETT is computed in Table 9. According to the results IETT has a debt-equity ratio of 3,62 for the period 2014-2016. This is indicating that the funds taken from 3rd parties are 3,62 times higher than the funds obtained from the shareholders. The previously high figure was noticed by the authorities, and investments are postponed. The equity is also increased to achieve a better result.

Table 9 - Debt - Equity Ratio

\begin{tabular}{|lll|l|}
\hline $\begin{array}{l}\text { Debt- } \\
\text { Equity } \\
\text { Ratio }\end{array}$ & Total Debt $\quad /$ Total Equity & Results \\
\hline 2014 & $1.745 .373 .699,37 / 288.379 .277,66$ & $=6,05$ \\
\hline 2015 & $1.529 .013 .715,23 / 340.754 .487,10$ & $=4,49$ \\
\hline 2016 & $1.513 .918 .373,42 / 4.801 .179 .857,32$ & $=0,32$ \\
\hline & & Average & $=3,62$ \\
\hline
\end{tabular}

The improved figure of IETT is relatively better than the industry. The industry averages given in Table 10, show that both ESHOT and EGO have negative equity.

Table 10 - Industry Average - Debt - Equity Ratio

\begin{tabular}{|l|l|l|l|l|}
\hline \multicolumn{5}{|l|}{ Industry Average } \\
\hline Year & \multicolumn{1}{l}{ IETT } & \multicolumn{1}{l|}{ ESHOT } & \multicolumn{1}{l|}{ EGO } & Average \\
\hline 2014 & 6,05 & $-31,77$ & $-2,69$ & $-9,47$ \\
\hline 2015 & 4,49 & 3,21 & $-2,53$ & 1,72 \\
\hline 2016 & 0,32 & 1,57 & $-2,23$ & $-0,12$ \\
\hline Average & 3,62 & $-9,00$ & $-2,49$ & $-2,62$ \\
\hline
\end{tabular}

\subsubsection{Equity Multiplier}

The calculation of equity multiplier is given in Table 11. Accordingly, IETT has an average equity ratio of 4,62. It is also seen that the ratio has decreased considerably in 2016. This is an indicator of less risk.

Table 11- Equity Multiplier

\begin{tabular}{|c|c|c|c|}
\hline Equity Multiplier & Total Assets & / Total Equity & Results \\
\hline 2014 & $2.033 .752 .977,03$ & / 288.379.277,66 & $=7,05$ \\
\hline 2015 & $1.869 .768 .202,33$ & / $340.754 .487,10$ & $=5,49$ \\
\hline \multirow[t]{2}{*}{2016} & $6.315 .098 .230,74$ & / $4.801 .179 .857,32$ & $=1,32$ \\
\hline & & Average & $=4,62$ \\
\hline
\end{tabular}

The industry averages for equity multiplier are available in Table 12. Accordingly, IETT is in a better position than both ESHOT and EGO. 
Table 12 - Industry Average - Equity Multiplier

\begin{tabular}{|l|l|l|l|l|}
\hline \multicolumn{2}{|l}{ INDUSTRY AVERAGE } \\
\hline YEAR & \multicolumn{1}{l}{ IETT } & \multicolumn{1}{l|}{ ESHOT } & \multicolumn{1}{l|}{ EGO } & \multicolumn{1}{l|}{ AVERAGE } \\
\hline 2014 & 7,05 & $-30,77$ & $-1,693$ & $-8,47$ \\
\hline 2015 & 5,49 & 4,21 & $-1,534$ & 2,72 \\
\hline 2016 & 1,32 & 2,57 & $-1,232$ & 0,88 \\
\hline AVERAGE & 4,62 & $-8,00$ & $-1,49$ & $-1,62$ \\
\hline
\end{tabular}

\subsubsection{Long Term Debt Ratio}

Table 13 shows the long term debt ratio of IETT. Accordingly, IETT has an average of 0,49 for the period 2014-2016. It is also seen that the ratio has decreased considerably.

Table 13- Long Term Debt Ratio

\begin{tabular}{|c|c|c|c|c|}
\hline Long Term Debt Ratio & Long Term Debt & 1 & $\begin{array}{l}\text { Long Term Debt }+ \\
\text { Total Equity }\end{array}$ & Results \\
\hline 2014 & $610.696 .060,87$ & / & $899.075 .338,53$ & $=0,68$ \\
\hline 2015 & $670.613 .057,42$ & l & $1.011 .367 .544,52$ & $=0,66$ \\
\hline \multirow[t]{2}{*}{2016} & $761.857 .972,08$ & l & $5.563 .037 .829,40$ & $=0,14$ \\
\hline & & & Average & 0,49 \\
\hline
\end{tabular}

The long term ratio of the industry is given in Table 14. IETT has a better long term ratio too when compared with ESHOT and EGO.

Table 14- Industry Average - Long Term Debt Ratio

\begin{tabular}{|l|l|l|l|l|}
\hline \multicolumn{5}{|l|}{ Industry Average } \\
\hline YEAR & IETT & ESHOT & EGO & AVERAGE \\
\hline 2014 & 0,68 & 1,06 & $-1,155$ & 0,19 \\
\hline 2015 & 0,66 & 0,57 & $-0,886$ & 0,12 \\
\hline 2016 & 0,14 & 0,32 & $-0,419$ & 0,01 \\
\hline AVERAGE & 0,49 & 0,65 & $-0,82$ & 0,11 \\
\hline
\end{tabular}




\section{Discussion}

In the research there are 7 different financial ratios. ( 3 for the liquidity ratios and 4 for the solvency ratios) The financial ratios are calculated individually for the three different institutions and also industry average is provided.

The first group of ratios is liquidity. And the results are indicating that the industry as a whole has a very illiquid structure. The average of current ratio is especially critically low for this group. The other ratios are also indicating low level of illiquidity.

The first ratio that is computed is current ratio. The industry average is 0,46 where all of the ratios are less than one. This amount indicates that the institutions have negative net working capital. This means that their current assets are lower than their current liability. This could create problems to repay short term debts. Individually ESHOT from Izmir have better current ratio 1,01 in average but less than one - 0,85 in 2016. The others have even lower ratios.

Another ratio in the liquidity ratios group is acid test ratio. It is computed by subtracting inventory from current assets. Due to low levels of inventory, acid test ratios are close to cash ratios. Industry average is 0,39. This is due to higher average of ESHOT from Izmir - 0,87 where the others are below acceptable level.

The final ratio in this group is cash ratio. This is calculated by dividing cash to the current liabilities. The industry average of this ratio is 0,07 . IETT from Istanbul has the highest cash ratio $-0,12$. The cash ratio for EGO from Ankara is less than 1\% which is critically low. This ratio indicates the ability to make immediate cash payments to cover current liabilities.

The second group of ratios is solvency ratios. They are mostly relied on when considering the ability to repay debts. They are considered superior to liquidity ratios in calculating solvency especially with long term debts. (Non-current liabilities) They are critical in this analysis especially because of high financial leverage and low level of capital. (Even negative for ESHOT from Izmir and EGO from Ankara).

The first ratio calculated in this group is total debt ratio. This shows how the assets are financed. Ratios more than 50\% means that the assets are financed more with debt. Due to a capital increase in 2016, IETT from Istanbul has $24 \%$ value which is an acceptable value. This means that most of the assets are financed with shareholders' equity. For ESHOT from Izmir, the value is $61 \%$ and EGO from Ankara $181 \%$. Mathematically, the only way this figure is more than $100 \%$ is that it has a negative shareholders' equity.

Then Debt-Equity ratio is given for this group. Ratios more than one show that the companies have more debt than shareholders' equity. IETT from Istanbul has an average of 3,62 although in 2016 the value is $32 \%$ due to a capital increase. In the same year the value of ESHOT from Izmir is 1,57 and that of EGO from Ankara is $-2,49$. Therefore IETT from Istanbul has a better capital structure then ESHOT from Izmir and EGO from Ankara. The negative value of EGO from Ankara indicates that the shareholders' equity is negative due to high losses in the previous periods.

Another ratio that is available in the research is Equity multiplier. This ratio shows how many times the assets are when compared to shareholders' equity. The ratio of IETT from Istanbul in 2016 is 1,32 which is acceptable, that of ESHOT from Izmir is 2,57 which is riskier, and that of EGO from Ankara is -1,49 which is an indicator of negative shareholders' equity.

The final ratio calculated for this group is long term debt ratio. The financial leverage of IETT from Istanbul is low as known from the previous ratios. This ratio in 2016 is also 14\%. ESHOT from Izmir 32\%. This seemingly low value has to be analyzed together with total debt ratio which was calculated before as $61 \%$. This shows that the company has considerable short term debt. $-41 \%$ value of EGO from Ankara means that the company has negative and critical capital structure.

\section{Conclusion}


State owned companies are responsible for public transportation in many cities. These companies have performance based budgets. These budgets force the companies to work efficiently. Moreover, they are subject to various kinds of risks.

Some of these risks are operational such as accidents that might partially be transferred via insurance. It is also possible to include emission based performance indicators. There are also pressures to have high return on assets, or low operating expenses which are profitability based performance indicators.

Another issue to be considered is how to finance these operations. Since it is a government owned field, there are many grants and subsidies involved. This may risk the financial viability of the project.

The risks also arise due to short term - liquidity based and long term solvency based concerns. Borrowing too much and irrationally may lead to problems in the system. The operations will continue to work due to governments acting as a buffer with grants to those companies. However without a self-sufficient system, problems may arise especially in times of financial crises.

The research involves financial analysis of public transportation companies that operate in Istanbul, Ankara, and Izmir. Accordingly companies have a critically low current ratio which indicates low level of liquidity.

For solvency, the ratios are even worse for most of the companies. They represent very high degree of financial leverage and negative shareholders' equity. This means that the companies work with high debt which might cause problems to repay without government support. It also indicates that they have such a bad performance in previous financial periods so that they have losses more than the shareholders' equity.

The paper has important practical and academic consequences. To sum up it is required to rethink the structure of the industry. A performance based, self-sufficient system is advisable for those companies.

\section{Bibliography}

[1] Akca E.C. (2007), "Latest Major Developments in Shipping Finance” Jornal of Black Sea and Mediterranean Environment, Vol.13, p.181.

[2] Akguc O. (1995), "Mali Tablolar Analizi”, Muhasebe Enstitusu, Vol. 9, pp.29-30.

[3] Arat M.E., Durmus A.H. (2000), "Isletmelerde Mali Tablolar Tahlili”, Nihat Savar Egitim Vakfi Yayinlari, Vol.5, p.95.

[4] Aydin N., Basar M., Coskun M. (2007), "Finansal Yonetim”, Detay Yayincilik, p.176.

[5] Anna Matas J. A. , Raymond J.L. (2003) "Redistributive Effects of Subsidies to Urban Public Transport in Spain", Transport Reviews, Vol.23, No.4, p. 433.

[6] Bekefi Z., Kiss L.N., Tanczos K., (2003), "Multicriteria Analysis of Financial Feasibility of Transport Infrastructure Projects in Hungary", INFOR, Vol. 41, No.1, p.124.

[7] Cabuk A., Lazol I. (2009), “Mali Tablolar Analizi”, Ekin Yayınevi, p.180.

[8] Nieplowicz M., (2016), "The Use of Performance Based Budget to Measure the Efficiency of Public Transport in Metropolises in Poland", Research Papers of Wrocklaw University of Economics, Vol.434, p. 125.

[9] Okka O., (2010), Isletme Finansmani A, Nobel Yayinevi, Vol.4, pp.118-119.

[10] Pintea M.O., Achim S.A., Gavriletea M., (2015), "Performance Evaluation in Urban Public Transportation”, Review of Economic Studies and Research Virgil Madgearu, Vol.2, p.82.

[11] Poliak M., Stefania S., Mrnikova M., Komackova L. , Simurkova P., (2017), "Financing Public Transport Services from Public Funds", Transport Problems, Vol.12, No.4, p.70.

[12] Vasallo J.M., Villar P.P., Raskin R.M., Serebrisky T., (2009), "Public Transport Funding Policy in Madrid: Is There Room for Improvement?", Transport Reviews, Vol.29, No.2, p.261. 
[13] Wang Y., Zhao J., (2014), "Determinants of Public Private Partnership in State Toll Road Financing", Public Performance and Management Review, Vol.37, No.4, p.679. 